\title{
SEMIPRESIDENCIALISMO E SEMIPARLAMENTARISMO (*)
}

Miguel Reale

Um dos assuntos que mais suscitará debates no seio da Assembléia Nacional Constituinte - ao lado dos poderes conferidos ao Estado na vida económica - será, certamente, o relativo ao regime de poderes. Agora mesmo, já se pode notar a divisão de nossos políticos e juristas em quatro correntes bem demarcadas: uma fiel a tradiçăo presidencialista; outra que pretende adotar o parlamentarismo clássico, de estilo britânico; a que acolhe certos valores do parlamentarismo, sem subordinaçăo do Executivo ao Congresso Nacional; e, finalmente,a que, em áltima análise, submete o Chefe da Naçáo ao poder eminente do Parlamento. A estas duas últimas posiçós denomino, respectivamente, "semipresidencialismo" e "semiparlamentarismo"

Se os defensores do parlamentarismo clássico constituem reduzida minoria, pode-se dizer que a definiçāo constitucional dependerá do predominio das trés outras posiçōes, que é necessário analisar cuidadosamente. Se os presidencialistas alardeiam os méritos de uma forma de governo marcada, a seu ver, pelos valores da eficácia e da estabilidade, os outros podem provar, com facilidade, que essa afirmaçăo não é confirmada pela recente história republicana. Em verdade, no regime presidencial, a partir da Revolução de 1930, cada eleiçăo do Presidente da República tem redundado numa crise institucional. Assim foi, em 1937, quando as candidaturas de Armando de Salles Oliveira e José Américo de Almeida, que abriram espaço a implantaçáo do Estado Novo; assim foi, em 1956, com a sucessāo do Presidente Joăo Café Filho, sucessor do Presidente Getúlio Vargas (e o suicfdio deste grande lfder assinalou outra crise do Presidencialismo)

- Capftulo VIII do lívro: Liberdade e Damocracia Ed. Saraiva, Sāo Paulo, 1987. 
sendo notorio que Juscelino Kubitschek só logrou tomar posse graças a intervençáo militar do Ministro da Guerra, Mal. Henrique Teixeira Lott, provocando levante parcial da Armada e significativa abdicaçāo por parte do Supremo Tribunal Federal: assim foi com a renúncia do Presidente Jânio Quadros, explodindo uma crise que, apos uma experiencia parlamentarista feita de afogadilho, culminou, em 1964, com o advento do regime militar. Uma história dessa natureza não $\epsilon$, positivamente, enaltecedora das virtudes do regime presidencial...

Tudo aconselha, a meu ver, a tentar novos caminhos, mas com a devida cautela, a fim de náo recairmos nos excessos que eu tenho simbolizado com a imagem de um movimento pendular desequilibrado, ora no sentido do Executivo, ora do Legislativo. Tenho meditado muito, estes ultimos meses, sobretudo à vista do triste desempenho de nossos partidos políticos durante a eleiçăo de 15 de novembro de 1986, e isto levou-me a rever a posiçăo, tomada no seio da Comissão Provisória de Estudos Constitucionais, a favor do semiparlamentarismo, mesmo porque a votaçăo final, como resulta do Anteprojeto de Constituiçăo publicado, redundou no abandono de uma soluçăo prudente, por mim defendida que preservava a autoridade do Presidente da República, ao qual era assegurada a faculdade de escolher o PrimeiroMinistro, ouvido o Conselho de Estado, na hipotese de ser, por duas vezes, recusado o nome por ele submetido à aprovaçăo da Camara dos Deputados. Entendeu-se preferivel conferir a esta o poder de impor o Presidente do Conselho de Ministros, a revelia de um Chefe da Naçăo eleito por sufrágio universal, o que me parece năo apenas incoveniente, mas irreal e absurdo.

Foi por esta razáo que, em artigo publicado na Folha de S. Paulo, logo após a decisáo da Comissão, declarei que pouco restara do apregoado "dualismo de complementariedade ", sendo previsivel, no Bra.. sil, a crise que resultaria da imposiçăo de um Primeiro-Ministro em conflito com o Presidente da República, por ser este o Chefe de Estado e comandante das Forças Armadas, e aquele o Chefe da Administraçăo... Como de outro lado, se outorga ao Presidente da República o poder de exonerar o Presidente do Conselho, bem se pode imaginar a inconsistencia do sistema aprovado.

Explica-se, desse modo, minha opçăo atual pelo semipresidencialismo, originariamente por mim aceito, e que continuou sendo defendido por Miguel Reale Júnior, que por sinal elaborou um projeto parcial de Constituiçăo disciplinando essa matéria, conforme consta do fascículo $\mathrm{n}^{\circ} 21$ da Revista do Advogado, publicada pela Associaçáo dos Advogados de S5o Paulo.

Outro ponto que pesou em meu espírito para tornar a acolher a tese do semipresidencialismo é o que resulta de nossa recente experiencia polítca, que tem mostrado a necessidade de ser o Presidente da República assessorado por um Ministro-Coordenador, funçâo esta que tem sido exercida ora pelo Chefe da Casa Civil, ora pelo Ministro do Planejamento. Penso que, para maior harmonia do Executivo com o Le- 
gislativo, deva caber a este aprovar a escolha do mencionado Ministro-Coordenador, que atuará assim como uma autoridade mediadora entre o Presidente da República e o Congresso Nacional. De outro lado, é assegurada à Camara dos Deputados como expressáo direta da vontade geral do eleitorado, a faculdade de opor veto de desconfiança a qualquer Ministro de Estado, năo sendo compreensivel, com efeito, que o Chefe da Naçăo, por afeiçăo pessoal ou desfdia, persevere em manter no poder um Ministro contra os ditames da opiniăo pública.

Além disso, com o semipresidencialismo, será fortalecida, equilibradamente, a posição do Congresso Nacional, o que permitirá a formaçăo de agremiaçóes polfticas distintas por suas opçס̄es ideologicas, ou, pelo menos, por seus programas de governo, pois é irrecusável que o presidencialismo em vigor, concentrando imensos poderes nas máos do Presidente da República, tem favorecido a polftica personalista, e constitufdo um dos fatores determinantes da ausencia de verdadeiros partidos nacionais, em geral conglomerados de múltiplas opinióes e interesses.

Nítida é a distinçăo entre semipresidencialismo e semiparlamentarismo. No primeiro, embora o Ministro-Coordenador seja nomeado com a aprovaçáo da Camara dos Deputados, há apenas um Chefe de Estado, que ê o Presidente da República, a quem cabe presidir o Conselho de Ministros, exercendo as suas funçóes com a colaboraçăo do Ministro-Coordenador, expressáo que prefiro à de Primeiro-Ministro, porquanto suas atribuiçóes sáo propriamente de assessoramento direto do Chefe do Executivo, de quem poderá receber delegaçăo para supervisăo de determinados atos de natureza administrativa.

Já no semiparlamentarismo, estamos perante dois Chefes de Estado, um eleito diretamente pelo povo, para exercicio das atribuiçós de soberania, e um outro que, segundo o modelo aprovado pela $\mathrm{Co}$ missão Provisoria de Estudos Constitucionais, poderá ser expressão de escolha feita unicamente pela Camara dos Deputados, em conflito com - Presidente da República. Antes se pensara, como salientei, num "dualismo de complementariedade", preservado graças a mediaçăo do Conselho de Estado, constituído com a mais ampla participaçáo parlamentar e cultural, mas a decisăo final desequilibrou mais uma vez o pêndulo político no sentido do Legislativo. A bem ver, há mais dualismos de complementariedade no semipresidencialismo aqui exposto, do que na formula semiparlamentar afinal adotada pela "Comissáo Arinos", com um Presidente de Conselho imposto unilateralmente pela Cámara dos Deputados.

Dir-se-à que ao Presidente da República se reservou competencia para exonerar o Presidente do Conselho, mas esta prerrogativa somente pode agravar o conflito de atribuiçőes, gerando nociva instabilidade nos serviços públicos.

Se pensarmos outrossim, que, no modelo semiparlamentarista, que 
estamos analisando, o Presidente da República, salvo no primeiro e último semestre de cada legislatura, poderá dissolver a Cámara dos Deputados, ouvido o Conselho de Estado, fica patenteada a fragilidade dessa concepçăo institucional, que scria fonte inesgotável de crises estruturais.

Além disso, é previsivel que a hipótese de dissoluçăo da Câmara dos Deputados será dificilmente acolhida por parlamentares que, no contexto da realidade eleitoral brasileira, tal como o demonstrou a tormentosa eleiçăo de 15 de novembro de 1986, sabem a duras penas quais os custos económicos, psicológicos e polfticos de um pleito federal. Apesar de dever o legislador resolver segundo princípios superiores às contingéncias pessoais, manda o realismo político que se atente a cssa conjuntura, nāo havendo seduçăo utópica - e nāo contesto que certa dose de utopia é aconselhável quando se elabora uma Constituiçăo que possa prevalecer no caso em apreço.

De mais a mais, o exemplo francês de um dualismo de poder está af diante de nossos olhos, mostrando que ele, naa prática, pode ser tanto de complementariedade como de confronto e neste caso, com gravíssimos danos a sociedade civil e ao Estado, pondo em risco o binomio essencial "liberdade-democracia".

Ninguém contestará que há necessidade de estabelecer certas medidas de contençáo dos poderes do Presidente da República, para que ele atue em mais íntima correlaçáo com os representantes do povo. Ora, a idéia de instituir-se um Ministro-Coordenador atenderá tanto a esse desideratum, assim como a necessidade de desvencilhar a Presidencia da Republica de encargos que, sem prejufzo da unidade estatal, poderáo ser delegados ao Ministro-Coordenador, cujo papel maior consistirá em auxiliar a co-gestāo đos serviços administrativos e manter um elo permanente com o Parlamento.

Alegar-se-d que a sobrecarga de funçōes administrativas, incomparavelmente maior, náo tem impedido o Presidente dos Estados Unidos da América de cuidar das atribuiçốes de soberania interna e internacional, mas a situaçáo brasileira tem peculiaridades que não podem deixar de ser consideradas. Em primeiro lugar, há menos tendencia, na grande República do Norte, para os generalizados e constantes apelos que, no Brasil, sáo dirigidos ao Chefe de Naçăo para obter seu pronunciamento pessoal sobre problemas, cujo exame, nos Estados Unidos da América, nǎo vai além de suas Secretarias de Estado. Alem disso, há que levar em conta a independencia do empresariado yankee, assim como da classe trabalhadora, tais as virtudes de iniciativa e de dinamismo autônomos próprios de sua socicdade civil e o individualismo congênito de sua gente. Em segundo lugar, năo olvidemos a existência de um federalismo auténtico, c cquilibrado, que a multiplicidade de grandes Estados possibilita c preserva; c, finalmente, uma poderosa estrutura administrativa que resolve, $\mathrm{cm}$ scus quadros, os problemas locais ou regionais, impedindo-lhcs o acesso as esferas superiores da administraçāo federal. 
No Brasil, ao contrário, herdamos do Império o centripetismo da Corte, reforçado pelas caréncias das regióes em que a natureza $\epsilon$, no dizer desolado de José Américo de Almeida, menos mãe do que madrasta. Nem e demais lembrar que a carencia de quadros partidários institucionalizados priva-nos de canais seletivos de pretensōes, de tal modo que todas as reivindicaçóes convergem para a Presidencia da República, através do contato pessoal de dezenas de deputados e senadores, lídimos interpretes de uma polftica de clientela.

Outro fator que deve ser considerado é certo "familiarismo poIf́tico" que se vai formando em torno da figura do Presidente da República, pouco propenso a alterar o seu Ministério, quer por afeiçס́es pessoais, quer pela fluidez das forças parlamentares em que se apóia. O certo é que, sobretudo durante o regime de exceçăo, o País se viu obrigado a tolerar ministros ou autoridades eminentes desprovidos de qualquer apoio na opiniāo pública.

Poderia acrescentar outras razóes đenunciadoras da necessidade de processar-se uma correlaçăo mais estável e sincrónica entre os Poderes Legislativo e Executivo, mas creio que as invocadas já sejam bastantes para fornecer-nos um quadro "sociologico-político", em funçăo do qual $e$ mister procurar adequadas soluçōes constitucionais.

Não obstante a devoção de polfticos ilustres como o eminente Raul Pilla e seus sucessores ideológicos, a maioria de nossos politicólogos e juristas - muito embora admitindo como é o meu caso, a superioridade do Parlamentarismo no plano teórico da democracia representativa - reconhece que tal soluçăo năo se compadece com as atuais circunstáncias do pafs, dada a falta de configuraçăo programática de nossas agremiaçōes partidárias e a gigantesca crise económico-financeira que está exigindo, mais do que nunca, bases estáveis para a ação governamental. Como o demonstrou Fernand Braudel, a história $€$ um tecido de "conjunturas", as vezes imprevistas, mais do que a expressão de planos e modelos preconcebidos.

Impōe-se, por conseguinte, encontrar uma via de soluçăo constitucional para tāo complexo sistema de fatores, de tal modo que a almejada estabilidade surja de uma conjugaçăo harmonica entre o Legislativo e o Executivo, de tal sorte que, alem de se reduzir a elefanIfase burocrática de que padece o segundo, possa o Congresso $\mathrm{Na}$ cional compartilhar das responsabilidades do Governo, inclusive no que se referc ao quadro cada vez mais alarmante das entidades estatais ou paraestatais que assinalam perigosa perda de unidade de poder.

Criar um governo de Gabinete com um Primeiro-Ministro cercado de prerrogativas de Chefe do Estado, lado a lado com um Presidente eleito diretamente pelo povo, seria voltarmos à soluçăo de emergencia configurada cm 1962. Na época, pleitcci, em livro intitulado Parlamentarismo Brasileiro, a permanencia dessa forma de governo, mas com alteraçócs substanciais por estar certo de que, restabelecido o regime presidencial, Joāo Goulart nāo estaria $\mathrm{cm}$ condiçōes de continuar à 
testa da República. Verdade é que a Jango, educado nos meandros do caudilhismo, faltava altitude para dirigir, sobranceiramente, um governo parlamentar, tantas foram as razōes de mágoa e de ressentimento dele e de seus "amigos", que se sentiam privados do poder presidencial.

Além disso, o Parlamentarismo entåo instituldo era minado por um vício radical, consistente em dualismo no exercício das atribuiçōes governamentais, dizendo-me, certa feita, o saudoso amigo Tancredo Neves que era impossivel governar, com o Primeiro-Ministro elaborando projetos de leis ao depois vetados pelo Presidente da República, obediente às ambiçōes e preferencias que o cercavam, por demais fiados.em seus ilusorios "dispositivos militares". Seria grande erro reestabelecer tal estado de coisas.

Foram todas as razōes até agora sumariadas que, como já recordei, fizeram surgir, num primeiro momento, no seio da Comissão Constitucional, a idéia de uma solução original, sem símile no Direito Constitucional alienfgena, com base na instituiçăo de um MinistroCoordenador, com as atribuiçōes e a missāo que tive a oportunidade de expor. E a essa idéia que retorno, penitenciando-me de té-la abandonado, movido pelo desejo de alcançar uma soluçāo conciliadora. Tal correçăo de rumo resulta da verificação experiencial no Brasil e no estrangeiro, dos riscos que rondam a partilha do Poder entre dois Chefes de Estado.

Nada há de criticável em meu retorno à posiçăo originariamente assumida, pois a verdade, tal como o esclarece Karl Propper, é alcançada mediante reiteradas tentativas de acerto e contínuas correçoes de erro. Essa é a coragem que se deve exigir do homem de ciencia, tanto no campo das ciencias naturais, como no das ciencias humanas, notadamente nos domfnios da Polftica, que é a ciencia do possível e a arte de tornar o possfvel uma realidade em funçăo do bem comum.

De mais a mais, o que se dá é uma mudança de enfoque na compreensāo do dualismo de complementariedade. Ao invés deste se estabelecer entre o Presidente da República e o Presidente do Conselho tal como ocorre no semiparlamentarismo - passa a operar entre o Presidente da República e a Camara dos Deputados: o elemento de mediaçáo entre estes dois órgãos e o Ministro-Coordenador. Desse modo, abre-se caminho à colaboraçăo e ao entendimento, e năo a um conflito entre dois Chefes de Estado. 